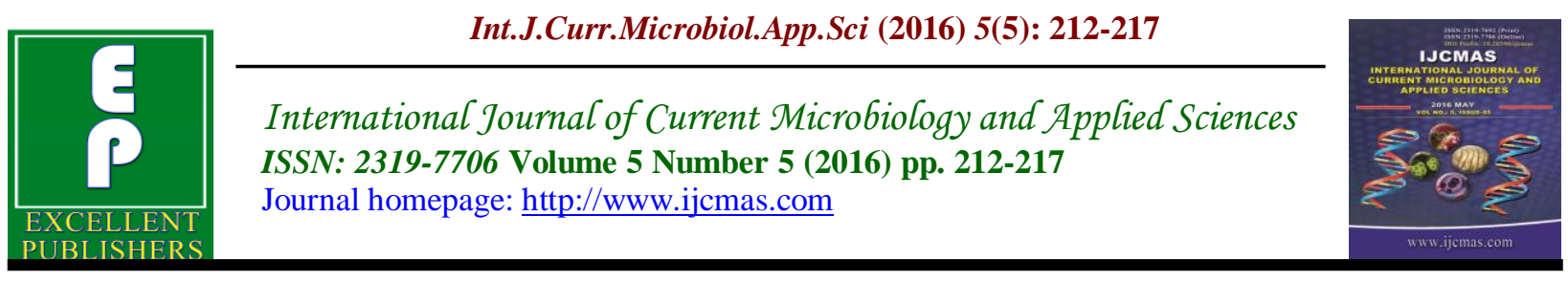

Original Research Article

http://dx.doi.org/10.20546/ijcmas.2016.505.023

\title{
Uptake of Nanoparticles by Coelomic Cells of Earthworm Eudichogaster prashadi
}

\author{
Shweta Yadav* \\ Department of Zoology, Dr H S Gour Vishwavidalaya, \\ (A Central University), Sagar MP, India \\ *Corresponding author
}

\begin{tabular}{|c|c|}
\hline & A B S T R A C T \\
\hline Keywords & \multirow{4}{*}{$\begin{array}{l}\text { Earthworms are significant ecological receptor species that play a key role } \\
\text { in the structure and function of soil ecosystems. They can absorb intact } \\
\text { nanomaterials and excrete into the form of aggregates. Bio-distribution of } \\
\text { nanoparticles into tissues and their accumulation plays a significant role in } \\
\text { assessing ecological risk and toxicity. Present study shows that coelomic } \\
\text { cells of earthworms can uptake nanoparticles } \sim 22.0 \% \text { at } 48 \text { hrs exposure of } \\
35 \mathrm{~nm} \mathrm{ZnO} \text {. The strategy of earthworms to accumulate nanoparticles and } \\
\text { excrete them in agglutinated/aggregated forms may exploit to remediate } \\
\text { nanoparticles from soil system at large scale. }\end{array}$} \\
\hline $\begin{array}{l}\text { Nanoparticles, } \\
\text { coelomic cells, } \\
\text { earthworm, } \\
\text { Eudichogaster } \\
\text { prashadi. }\end{array}$ & \\
\hline Article Info & \\
\hline $\begin{array}{l}\text { Accepted: } \\
\text { 12 April } 2016 \\
\text { Available Online: } \\
10 \text { May } 2016\end{array}$ & \\
\hline
\end{tabular}

\section{Introduction}

The applications of nanaomaterials have gained wide attention because of their novel properties including large surface area and high reaction activity. Despite of their bright future outlook there is growing concern about human health, safety and environmental impacts including from exposure to engineered nanomaterials from different environmental sources. Through normal use of nanoparticles, NPs may be released from various products and enter into wastewater stream. A major portion of these nanoparticles, may release into sewage sludge those are disposed of in landfills, incinerated or applied to agriculture lands. Thus, soil system is an alternative sink for large portion of nanoparticles (Gottschalk et al., 2009).
Earthworms occupy major invertebrate biomass $(>80 \%)$ in terrestrial ecosystem and have over 600 million years of experience as environmental managers in the ecosystem. But some new discoveries about their role in bioremediation of industrial wastes, chemically contaminated soil, dairy industry waste material, and detergent industries have revolutionized the understanding of functioning of this unheralded soldier of mankind.

Annelids are supposed to be the earliest animals in phylogenetic tree in which both cellular and humoral immune responses are developed. Their body (coelomic) fluid consists various types of immunocompetent 
cells, the coelomocytes, which take part in various physiological processes including wound healing, blood coagulation, regeneration and other immune responses. These cells may expel out under stressful conditions through inter-segmental dorsal pores with increased intra-coelomic pressure. These coelomocytes can be classified into two basic categories; amebocytes (mainly immune function) and eleocytes (mainly nutritive function). However, a uniform classification of coelomocytes of different species of earthworm is little difficult (Adamowicz and Wojtaszek, 2001) as they exists in various functional states and stages of maturation. The amebocytes moves by pseudopodia devour foreign material and are rich in lysosome. While, eleocytes are rich in glycogen particles, lipid droplets and characterized by the presence of distinct yellow granules, chloragosomes. The origin and relationship of coelomocytes are not yet completely known. It has been assumed that amebocytes derived from mesenchymal lining of coelom whereas, eleocytes originate by detachment of chloragogen cells covering intestinal tract (Affar et al., 1998; Hamed et al., 2002). Amebocytes participate in the transport and storage of nutritive substances (Valembois et al., 1988), phagocytosis (Stein and Cooper, 1981; Bilej et al., 1990; Dales and Kalae, 1992; Ranzelli-Cain and Kaloustian, 1995; Cossarizza et al., 1996), while; eleocytes play an important role in immune responses producing bacterial substances (Valembois et al., 1982; Ville et al., 1995; Milochau et $a l ., 1997)$ and also participates in reaction of encapsulation and formation of brown bodies (Cooper and Stein,1981). The number and composition of coelomic cells depends on exogenous (environmental) as well as endogenous (biotic, life cycle) factors. Parry (1975) proved short-term and limited memory in coelomic cells of earthworms in transplantation experiments to autografts and xenografts. The study revealed coelomic cells of earthworm, Euduchogaster prashadi has significant capability to uptake NPs and eliminated through the dorsal pores/nephridia in agglomerated /hetero aggregated forms.

\section{Materials and Methods}

\section{Collection of Earthworms}

Eudichogaster prashadi (family Octochaetidae) were collected by digging and hand sorting method from botanical garden, agriculture land and reserved forest area of Sagar MP, India during August September, 2014. For identification, collected specimens were preserved in ethyl alcohol for molecular characterization, and also fixed in $4 \%$ formalin for morphoanatomical study. Coelomic cells were extracted from live earthworms and subcultured in $\mathrm{CO}_{2}$ incubator.

\section{Isolation of Coelomocytes}

Collected worms were thoroughly washed in running tap water before rinsing in distilled water and were not subjected to any control condition. Worms were placed on wet cotton to ensure complete defecation in order to avoid contamination during harvesting of coelomocytes. After 2-3 hrs, worms were wiped with cotton wool soaked with $70 \%$ ethyl alcohol to avoid any further contamination. The surface cleaned worms were placed alternately in sterile petridish containing cold extrusion buffer $(\mathrm{NaCl}$ $71.2 \mathrm{mM}$; Ethanol 5\%; Guaicol-glycerolether 50.4mM; EGTA 5mM, pH 7.3) and distilled water at interval of one minute for 8-10 times. Coelomic fluid extruded out through dorsal pores due to external stress condition. After collection of coelomic fluid in cold extrusion buffer, worms were released in soil. 


\section{Culturing of Coelomocytes}

The excreted coelomic fluid was pipette into tubes filled with LBSS solution $(\mathrm{NaCl}$ $71.5 \mathrm{mM} ; \mathrm{KCl} 4.8 \mathrm{mM} ; \mathrm{MgSo}_{4} .7 \mathrm{H}_{2} \mathrm{O} 1.1 \mathrm{mM}$; $\mathrm{KH}_{2} \mathrm{PO}_{4} 0.4 \mathrm{mM}, \mathrm{pH} 7.3$ ) and centrifuged at $4^{\circ} \mathrm{C}$ for 5 min. Loose pellets of coelomocytes were washed 2-3 times with cold LBSS solution. Cell count was maintained $10^{7} / \mathrm{ml}$ with trypan blue exclusion. The isolated coelomocytes were loaded in petridish with DMEM supplemented with $10 \%$ FBS and incubated for 3 days in $\mathrm{CO}_{2}$ incubator.

Exposure of Nanoparticles on Earthworms

Exposure of $\mathrm{ZnO}$ nanoparticles ( $35 \mathrm{~nm}$ ) were seeded in 96-well plate at $5 \times 10^{5}$ cells $/ \mathrm{ml}$ and treated at T, Control; T2-0.3; T3-5.0; $\mathrm{T} 4-8.0 \mathrm{mg} / \mathrm{l}$.

\section{Cell Viability}

Viability of cells was recorded at the time of isolation and after incubation for three days using haemocytometer and was examined in phase contrast and fluorescence microscope.

\section{Flow Cytometeric Assessment of Coelomic Cells}

The uptakes of nanoparticles by coelomic cells were examined using flow cytometeric method (Kumar et al., 2011). 50 pl treated and control culture was added into $950 \mu 1$ PBS and than analyzed with flow cytometer (FACS Canto II BD Biosciences, San Jose, CA) using FACS Diva 6.1.2 software (BD Biosciences). In the dot plots, $\mathrm{X}$-axis reflects the FSC intensity in logarithmic scale, and $\mathrm{Y}$-axis corresponds to the SSC intensity in linear scale. The gating of the data was based on SSC and FSC of the control cells and control cells, respectively. This allowed us to differentiate the cells in which internalization of nanoparticles occurred from those where there was either no internalization or there was internalization along with adsorption. Dead cell discrimination of the treated cells was carried out according to the protocol described by Jung et al., using propidium iodide dye.

\section{Results and Discussion}

Study demonstrated that cells after $48 \mathrm{hrs}$ exposure of $\mathrm{ZnO}-\mathrm{NP}$ exhibited an increase in intensity of the side scatter (SSC)) which was more pronounced with $\mathrm{T} 4(22.60 \%$ increase) rather than T2 \& T3 (20.44 and $21.05 \%$ increase) when compared with the control (Fig. 1). The dose-dependent increase in SSC intensity of treated cells can be attributed to increased internalization of ZnO-NPs however maximum uptake of NPs varied from $20.44-22.60 \%$ and not significantly varies with increase on dose of exposure of NPs.

Earthworms can uptake NPs from soil in two forms i.e. dietary pathways ( $\sim 95 \%$ of total uptake) and dermal pathways ( $\sim 5 \%$ of total uptake). However, their skin with mucus is the first-line defense barrier against foreign endeavor, but once they enter the coelom, they are exposed to cellular and humoral responses. The internalization of NPs in coelomic cells occurs due to TLR (toll like receptors) and their recognition is mediated by pattern-recognition receptors (PRRs, which leads into various inflammatory cytokines and antimicrobial peptides. Van der Ploeg et al., (2013) reported enzymes involved in antioxidant mechanism doesn't effect on exposure of $\mathrm{C}_{60}$ fullerenes on $L$. rubellus. However, coelomic cytolytic factor 1 (CCF1), a pattern recognition receptor was found suppressed in lifelong experiment. Clathrin-mediated 
endocytosis, caveolae- mediated phagocytosis and micro-pinocytosis may involve in uptake of NPs by coelomocytes. Scavenger receptor class A (a pattern recognition receptors) of coelomocytes is potential pathway to phagocytosis the NPs by amebocytes of earthworms.

Figure.1 Scatter Analysis of NPs uptake in Coelomic Cells of Eudichogaster prashadi after Exposure of 48hrs,(T1) Control;(T2) 2mg/l;(T3) 3mg/l;(T4) 5mg/l

\begin{tabular}{|c|c|c|c|c|c|c|c|c|}
\hline T1.Control & 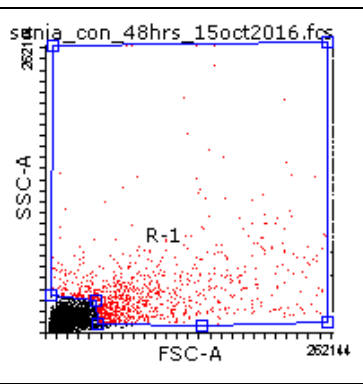 & H-2 & $\frac{\text { All event: }}{\mathrm{H}-2}$ & $\begin{array}{ll}\text { Events } \\
510,000 \\
898\end{array}$ & \begin{tabular}{l|l|}
$s$ & $\%$ of $\mathrm{Vi}$ \\
0 & 100,00 \\
& 8.98
\end{tabular} & \begin{tabular}{|l|l} 
is & Mean \\
& 98.76 \\
& 993.64
\end{tabular} & $\begin{array}{l}\text { Median } \\
12.45 \\
468.95\end{array}$ & \begin{tabular}{l|}
$\mathrm{CV}$ \\
831.59 \\
258.97
\end{tabular} \\
\hline T2.Eudi_3mg & 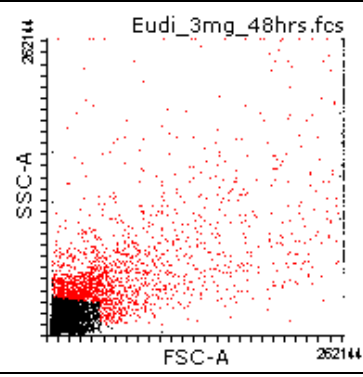 & Eudi_3mg_48hrs.fcs & $\begin{array}{l}\text { All events } \\
\mathrm{H}-6\end{array}$ & \begin{tabular}{l|l} 
Events & \\
10,000 & \\
2,044 &
\end{tabular} & \begin{tabular}{l|l}
$\%$ of Vis & 1 \\
100,00 & \\
20,44 &
\end{tabular} & \begin{tabular}{|l|l|} 
Mean \\
343.32 \\
$1,595.95$
\end{tabular} & \begin{tabular}{l|l} 
Median & $C$ \\
33.20 & 4 \\
571.87 & 18
\end{tabular} & $\frac{C V}{438.49}$ \\
\hline T3.Eudi_5mg & 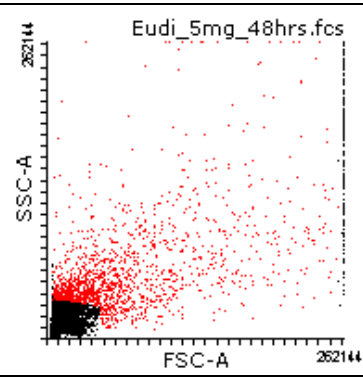 & Eudi_5mg_48hrs.fcs & \begin{tabular}{l|} 
All events \\
$\mathrm{H}-9$
\end{tabular} & \begin{tabular}{l|l|} 
Events & \\
10,000 & \\
2,105 &
\end{tabular} & \begin{tabular}{l|l|}
$\%$ of Vis \\
100,00 \\
21.05
\end{tabular} & \begin{tabular}{|l|} 
Mean \\
478,30 \\
$2,064,37$
\end{tabular} & \begin{tabular}{|l|l|} 
Median \\
34,03 \\
$1,185.24$
\end{tabular} & \begin{tabular}{|l|} 
CV \\
638,76 \\
141,35 \\
\end{tabular} \\
\hline T4.Eudi_8mg & 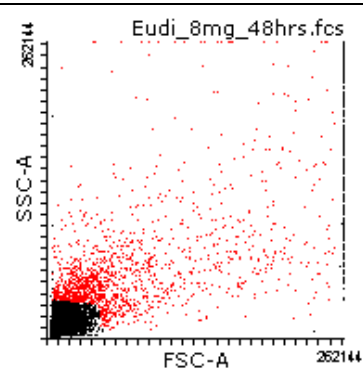 & 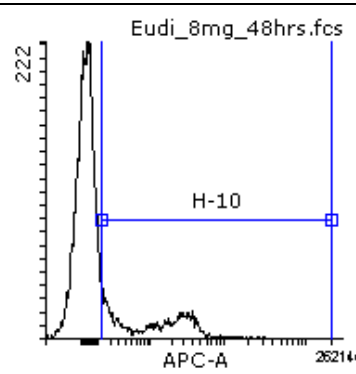 & $\begin{array}{l}\text { All events } \\
\mathrm{H}-10\end{array}$ & \begin{tabular}{l|l|} 
Events \\
10,000 \\
2,260
\end{tabular} & $\begin{array}{l}\frac{\% \text { of Vis }}{100,00} \\
22,60\end{array}$ & \begin{tabular}{l|} 
Mean \\
545,28 \\
$2,237,54$
\end{tabular} & \begin{tabular}{l|} 
Median \\
36,52 \\
$1,245,00$
\end{tabular} & \begin{tabular}{|l|}
$\mathrm{CV}$ \\
596,13 \\
210.88 \\
\end{tabular} \\
\hline
\end{tabular}

Macrophage receptor with collagenous structure (MACRO) of amebocytes recognizes and associates with nanoparticles for phagocytic clearance. Activation of calcium signaling on exposure NPs reflects stress and immune-responses like in highly conserved signal transduction cascade, MARK pathways. On the other hand, secretion/modulation of cytokine from phagocytes is also effected by NPs may be suggested as indirect effect of intracellular communication of coelomocytes during 
exocytosis of NPs in coelomic fluid as reported in our earlier studies(Gupta et al., 2014). Thus phagocytic population of coelomocytes seems to have potential to uptake NPs and excreted out in the form as aggregates to scavenging nanomaterials from the soil system.

\section{Acknowledgement}

We acknowledge the financial support of the Department of Biotechnology, Ministry of Science and Technology, Govt. of India, New Delhi, to carry out this study.

\section{References}

Adamowicz, A., Wojtaszek, J. 2001. Morphological and phagocytotic activity of coelomocytes in Dendrobaena veneta (Lumbricidae). Zoologica Poloniae, 46: 91-104.

Affar, E.B., Dufour, M., Poirier, G.G., Nadeau, D. 1998. Isolation, purification and partial characterization of chloragocytes from the earthworm species Lumbricus terrestris. Mol. Cell. Biochem., 185: 123-133.

Bilej, M., Vetvicka, V., Tuckova, L., Trebichavsky, I., Koukal, M., IMA, P. 1990. Phagocytosis of synthetic particles in earthworms : Effect of antigenic stimulation and opsonisation. Folia Biol., 36: 273.

Cooper, E.L., Stein, E.A. 1981. Invertebrate blood cells. Academic Press, London San Francisco, pp75-140.

Cossarizza, A., Cooper, E.L., Suzuki, M.M., Salvioli, S., Capri, M., Quaglino, Franeschi, C. 1996. Earthworm leucocytes that are not phagocytic and cross-react with several human epitopes can kill human tumor cell lines. Exp. Cell. Res., 224: 174-182.

Dales, R.P., Kalac, Y. 1992. Phagocytic defense by the earthworm Eisenia fetida against certain pathogenic bacteria. Comp. Biochem. Physiol., 101: 487-490.

Gottschalk, F., Sonderer, T., Scholz, R.W., Nowack, B. 2009. Modeled environmental concentrations of engineered nanomaterials $\left(\mathrm{TiO}_{2}, \mathrm{ZnO}\right.$, $\mathrm{Ag}, \mathrm{CNT}$, Fullerenes) for different regions. Environment Science \& Technology, 43(24): 9216-9222.

Gupta Shruti, Kushwaha Tanuja, Yadav Shweta. 2014. Earthworm Coelomocytes as nano- scavanger for $\mathrm{ZnO}$ NPs. Nanoscale Res. Lett., 9: 259-269.

Hamed, S.S., Kauchke, E., Cooper, E.L. 2002. Cytochemical properties of earthworm coelomocytes enriched by Percoll. In: A new model for analyzing antimicrobial properties with biomedical applications. Beschin, A., Bilej, M. and Cooper E.L.(Eds.), IOS Press, Ohmsha, pp 29-37.

Kumar, Ashutosh, Pandey Alok, Singh, S., Shashi, Shanker Rishi, Dhawan Alok. 2011. A flow Cytometeric method to assess nanoparticles uptake in bacteria. Cytometry, 707-712.

Milochau, A., Lassegues, M., Valembois, P. 1997. Purificaton, characterization and activities of two hemolytic and antibacterial proteins from coelomic fluid of the annelid Eisenia fetida andrei. Biochim. Biophys. Acta., 1337: 123-132.

Parry, M.J. 1975. Evidence of mitotic divisions of coelomocytes in the normal, wounded and grafted earthworm Eisenia fetida. Experientia, 32: 449-451.

Ranzelli-Cain, R., Kaloustian, K.V. 1995. Evidence for the involvement of opioid peptides in phagocytosis, conformation, granulation and aggregation of immunocompetent Lumbricus terrestris amoebocytes. Comp. 
Biochem. Physiol., 111: 205-211.

Stein, E.A., Cooper, E.L. 1981. Cytochemical observations of coelomocytes the earthworm, Lumbricus terrestris. Dev. Comp. Immunol., 5: 15-25.

Valembois. P., Roch. P., Lassegues, M. 1988. Evidence of plasma clotting system in earthworms. J. Invertebrates Pathol., 51: 221-228.

Valembois, P., Roch, P., Lassegues, M., Cassand, P. 1982. Antibacterial

activity of the hemolytic system from the earthworm Eisenia fetida andrei. $J$. Invertebrate Pathol., 40: 21-27.

Ville, P., Roch, P., Cooper, E., Masson, P., Narrbomnne, J. 1995. PCBs increase molecular-related activities (lysosome, antibacterial, hemolysis, proteases) but inhibit macrophage-related functions (phagocytosis, wound healing) in earthworms. J. Invertebr. Pathol., 65: 217-224.

\section{How to cite this article:}

Shweta Yadav. 2016. Uptake of Nanoparticles by Coelomic Cells of Earthworm Eudichogaster prashadi. Int.J.Curr.Microbiol.App.Sci. 5(5): 212-217.

doi: http://dx.doi.org/10.20546/ijcmas.2016.505.023 